\title{
IMPLEMENTATION OF TARGET COSTING IN INDONESIA: THE INFLUENCE OF DYNAMIC CAPABILITIES, DYSFUNCTIONAL BEHAVIOUR, AND SUCCESS FACTORS IN MANUFACTURING COMPANIES
}

\author{
Grahita Chandrarin ${ }^{1 *}$, Normah Omar', \\ Dani Yuniawan ${ }^{3}$ and Eni Lisetyati4 \\ $1 *$ University of Merdeka Malang, Indonesia \\ E-mail: grahitac@unmer.ac.id \\ ${ }^{2}$ Accounting Research Institute, Universiti Teknologi MARA, Malaysia \\ ${ }^{3}$ Faculty of Engineering, University of Merdeka Malang, Indonesia \\ ${ }^{4}$ Faculty of Economics and Business, University of Merdeka Malang, Indonesia
}

\begin{abstract}
The purpose of this research is to explore and describe the implementation of the Target Costing (TC) system as well as its effect on the dynamic capabilities (DC), success factors (SF) and dysfunctional behaviours (DB) of manufacturing firms in Indonesia. As there had been no prior research conducted on the consequences of the target costing implementation in Indonesia, this study, which had been one of the projects undertaken for improving the validity of variables and costing studies in Asia Pacific countries, was therefore performed by way of surveys along with the descriptive-quantitative and multiple regression analyses for gauging its impact on the company's internal and competitive environment. It was found that better company performance results (PR) had not only stemmed from a low DB level, but were also influenced by the resulting strong DC from the implemented TC system. Apart from demonstrating the target pricing systems as being a triggering factor of DB, this study also discovered SF as being an insignificant aspect for determining the successful implementation of the target costing system.
\end{abstract}

Keywords: target costing, dynamic capabilities, dysfunctional behaviour, target costing implementation, product pricing. 


\section{INTRODUCTION}

Since companies are now driven by competitive pressures, many have thus begun establishing quality improvement programmes as a way of extending the products' life cycle in the market. As a case in point, some of these strategies had included new product development, re-designing of old products, value engineering (VE), just-in-time (JIT), total quality management (TQM), materials requirements planning (MRP), kaizen philosophy, lean manufacturing applications (Mohamad \& Ito, 2013) as well as those of activity based costing, re-engineering process, total productive maintenance (TPM) and re-design performance measurements (Yuniawan et al., 2013; 2014), where the last few had concentrated on the functions, the manufacturability perspective, time and cost efficiency and the selection and dynamic cooperation between competent suppliers and manufacturers. However, as the cost budgeting that was practiced in the production lines and product distribution of all the above mentioned techniques had only concentrated on one cost area of production; a target cost system that specifies the product's functionality and quality can therefore be employed for ensuring the products' survival as well as its desired profit in the market. For this reason, this study on the implementation of target costing (TC) in the manufacturing companies in Indonesia is a continuation from previous research that was conducted on the company's financial management policy from the effects of board diversity (Herdhayinta et al., 2017) and market mapping in Indonesia (Suhardianto et al., 2017). TC is not just a costing method, but rather a management technique wherein prices are determined according to market expectations. As such, the key objective of TC lies in its proactive cost planning, cost management and cost reduction practices, where the costs are planned and calculated early in the design and development cycle, rather than during the later stages of product development and production (Yazdifar \& Askarany, 2011).

This research focused on 65 manufacturing companies in Indonesia that were selected through the simple random sampling method. In Indonesia, a majority of the businesses have still not realized the importance of implementing the TC system although many have managed to produce better and more innovative products in meeting market expectations and while a few companies had taken the step of implementing the TC concept in their new products development, there was still vagueness in the TC 
processes carried out. Hence, the results from this research will not only provide managers with a better understanding of the target pricing system, but also on the important aspects of target costing, such as its consequences on company performance, the resulted in $\mathrm{DB}$ during the course of target setting as well as the main SF and the DC of the firms that had implemented the TC method.

By referring to a previous research that was conducted by Alpenberg and Scarbrough (2013), where they had stated the TC performance result (PR) as being strongly influenced by the strong DC and a lower DB level, this study was thus carried out to observe if the resulted dysfunction behaviours (DB), success factors (SF) and dynamic capabilities (DC) of the managers from the implemented TC system had affected the performance results (PR) of the manufacturing companies in Indonesia. Therefore, aside from contributing to the characteristics observation of the manufacturing companies with an implemented TC system, this research that was conducted in Indonesia will also provide an insight in the handling of its research development towards the continuous improvement of a company.

\section{LITERATURE REVIEW}

Since this is the first time a study is conducted on the DC and DB managerial factors of a TC implementation in Indonesia, this section will first begin by reviewing some of the current literature concerning the TC methods that had been implemented in other countries as well as their respective influencing factors.

The term "TC" or genkakikaku was used for the first time in 1963 by Toyota Company (Meghabber, 2015) and since then, had been widely used in Japan (the pioneer country for TC implementation) and other countries alike.

In one of their studies, Dekker and Smidt (2003) had concluded the costing techniques employed by the Dutch listed manufacturing firms, where it had involved identifying a target cost through the subtraction of a necessity profit margin from an expected selling price, as being comparable to those of the TC concept. The significant difference between the involvements of the development/design and accounting departments of the TC that was 
practiced in the Dutch firms was also found to be similar to the Japanese circumstances, where the TC implementation on cost reduction had required a heavier engineering task than those of the non-engineering departments.

Since (Yazdifar \& Askarany, 2011) had found the TC implementation to be only relevant to manufacturing firms, the implementation of this method in the service firms was therefore excluded from this study. Apart from discovering no significant differences in the overall TC implementation rate (adoption versus non-adoption) between those of the manufacturing and service firms, the same authors had also noticed its low adoption rate in the UK, AU and NZ, which could have been due to the hesitation of the decision makers in further pursuing the TC method.

Another research that had contributed to the empirical substantiation on the role of TC in the process of new product development is VE (value engineering), where it is used to determine the allowable costs for each element in every major function of the product and to yield a cost-reduction purpose for each element (Afonso et al., 2008).

The importance of TtM (time to market) of new products as a factor of competitive advantage is also well acknowledged (Sherman et al., 2000). In this context, the speed of NPD (new product development) is found to be of importance for overcoming the rapid dwindling and obsolescence of product life cycles as well as coping with the fierce competition and an intense global market expansion (Sherman et al., 2000).

Firms that succeed in generating and marketing new products ahead of their competitors are also seen as attaining first mover advantages (Griffin, 2002), where the command of higher prices will not only help them to achieve top market share, but also customer loyalty. Since significant cost benefits can also arise from compressing the NPD cycle time (Gupta et al., 1992), it is therefore not surprising that the concept of a fast-tracked NPD is still being maintained for its strategic importance (González \& Palacios, 2002).

In brief, the reduction of TtM and the utilization of TC can be regarded as being the main contributions of the success of the NPD. Since the TtM is somewhat influenced by the types of practices or methods used, this 
research had thus attempted to prove the importance of TC in NPD, where its success can also be implemented beyond those of other methods (Afonso et al., 2008). The application of TC method from the 10 countries that had been highlighted from past research is shown in Table 1.

Table 1: TC Implementation in 10 countries

\begin{tabular}{|c|c|c|}
\hline Countries & Articles & Target Costing Application \\
\hline \multirow[t]{7}{*}{ Japan } & Kato (1993) & $\begin{array}{l}\text { Cost reduction and cost control focus in the early } \\
\text { stages of product life-cycles }\end{array}$ \\
\hline & Tani et al. (1994) & Engineering function involvement \\
\hline & Tani (1995) & $\begin{array}{l}\text { Strong power of managers of product planning, } \\
\text { development, detailed design, production } \\
\text { engineering, purchasing and sales. }\end{array}$ \\
\hline & Feil et al. (2004) & No involvement of financial or accounting function. \\
\hline & Huh et al. (2008) & Overlapped product development \\
\hline & & Simultaneous engineering involvement \\
\hline & & Target Costing Management (TCM) \\
\hline \multirow[t]{3}{*}{$\begin{array}{l}\text { United } \\
\text { States }\end{array}$} & $\begin{array}{l}\text { Hibbets et al. } \\
(2003)\end{array}$ & $\begin{array}{l}\text { A very tight linkage between supply management } \\
\text { and the design function in the TC practice }\end{array}$ \\
\hline & Ellram (2006) & $\begin{array}{l}\text { The involvement of R\&D, supply management and } \\
\text { suppliers are in the early stages of TC process }\end{array}$ \\
\hline & & $\begin{array}{l}\text { The impact of competitive environment and } \\
\text { strategy }\end{array}$ \\
\hline \multirow[t]{3}{*}{$\begin{array}{l}\text { New } \\
\text { Zeland }\end{array}$} & $\begin{array}{l}\text { Rattray et al. } \\
(2007)\end{array}$ & $\begin{array}{l}\text { More focus on cost reduction and satisfying of } \\
\text { customer needs. }\end{array}$ \\
\hline & & $\begin{array}{l}\text { High involvement of manufacturing, product } \\
\text { development and design in TC process }\end{array}$ \\
\hline & & Suppliers are not involved in TC process \\
\hline \multirow[t]{2}{*}{ India } & Joshi (2001) & $\begin{array}{l}\text { Low adoption rate indicates the uncertainty } \\
\text { avoidance factor, conservative attitudes of } \\
\text { managers, quite expensive to adopt, and lack of } \\
\text { training and expertise }\end{array}$ \\
\hline & & $\begin{array}{l}\text { TC adoption perceived better benefits and higher } \\
\text { emphasis. }\end{array}$ \\
\hline \multirow[t]{2}{*}{ Australia } & Chenhall \& & Low adoption, benefits and emphasis \\
\hline & $\begin{array}{l}\text { Langfield-Smith } \\
\text { (1998) }\end{array}$ & $\begin{array}{l}\text { The impact of firm size and Australian close culture } \\
\text { and business }\end{array}$ \\
\hline
\end{tabular}




\begin{tabular}{|c|c|c|}
\hline Countries & Articles & Target Costing Application \\
\hline \multirow[t]{3}{*}{ Netherland } & $\begin{array}{l}\text { Dekker \& Smidt } \\
(2003)\end{array}$ & $\begin{array}{l}\text { Cost reduction, timely product introduction and } \\
\text { customer satisfaction goals }\end{array}$ \\
\hline & & $\begin{array}{l}\text { The involvement of product development and } \\
\text { design departments }\end{array}$ \\
\hline & & No involvement of accounting department. \\
\hline \multirow[t]{6}{*}{ Turkey } & $\begin{array}{l}\text { Kocsoy et al. } \\
(2008)\end{array}$ & Pre-design customer analysis for setting TC \\
\hline & & Long-Term Product and Profit Planning \\
\hline & & $\begin{array}{l}\text { Use cross-functional team to determine cost and } \\
\text { cost reduction process. } \cdot \text { High use of simultaneous } \\
\text { engineering. }\end{array}$ \\
\hline & & $\begin{array}{l}\text { Less use of competition-oriented pricing method } \\
\text { in setting the price. }\end{array}$ \\
\hline & & $\begin{array}{l}\text { The common method in determining the profit } \\
\text { target is Return on Sales (ROS) }\end{array}$ \\
\hline & & $\begin{array}{l}\text { Cost estimations are determined during the } \\
\text { product designation phase. }\end{array}$ \\
\hline \multirow[t]{2}{*}{ Brazil } & $\begin{array}{l}\text { Filomena et al. } \\
(2009)\end{array}$ & TC operationalization model \\
\hline & & $\begin{array}{l}\text { Break down cost targets into: product parts, } \\
\text { product features, and product common elements }\end{array}$ \\
\hline \multirow[t]{3}{*}{ Sweden } & Ax et al. (2008) & $\begin{array}{l}\text { A positive relationship between TC adoption and } \\
\text { intensity of competition }\end{array}$ \\
\hline & & $\begin{array}{l}\text { A negative relationship between TC adoption and } \\
\text { PEU }\end{array}$ \\
\hline & & $\begin{array}{l}\text { The positive effect of intense competition on TC } \\
\text { adoption is moderated by PEU in a negative } \\
\text { direction. }\end{array}$ \\
\hline \multirow[t]{5}{*}{ Bahrain } & Juhmani (2010) & $\begin{array}{l}\text { No statistically significant relationship between TC } \\
\text { adoption and firm size. }\end{array}$ \\
\hline & & $\begin{array}{l}\text { High achievement of TC is associated with higher } \\
\text { performance. }\end{array}$ \\
\hline & & $\begin{array}{l}\text { High percentage use of low cost strategy in } \\
\text { adopting TC. }\end{array}$ \\
\hline & & $\begin{array}{l}\text { High adoption rate of } \mathrm{TC} \text { in redesigning existing } \\
\text { products. }\end{array}$ \\
\hline & & $\begin{array}{l}\text { High involvement o manufacturing department } \\
\text { in TC }\end{array}$ \\
\hline
\end{tabular}


As shown in Table 1, since it had been obvious that the TC implementation had not yet reached a full potential in Indonesia, this research had therefore aimed to observe the influence of extending a product life cycle from an implemented TC system on the manufacturing companies' performance in Indonesia.

\section{Contribution of Target Costing in a Company's Product's Life Cycle}

Regarded as a management process that is responsible for identifying, anticipating and satisfying customer requirements, the TC method is now being widely implemented in manufacturing firms as a means of attaining cost reduction and maintaining their profitability. Since it is a cost management technique that manages product costs during the earlier stages of a product life cycle, it is thus seen as being a more effective cost management method than those of the typical cost reduction and cost control activities, where it had only focused on the production phase.

Although Ellram (2006) had discovered the TC processes of 11 organisations in the United States (US) such as the identification of desired product characteristics, target selling price, product target cost, target cost allocated to bill of materials, cost management activities and continuous improvement as being similar to those of the popular TC model in Japanese companies, he had nevertheless observed a difference of the departments' involvement in some of the above mentioned processes (Hamood et al., 2011). An illustration of the TC process with its three elements is depicted in Figure 1.

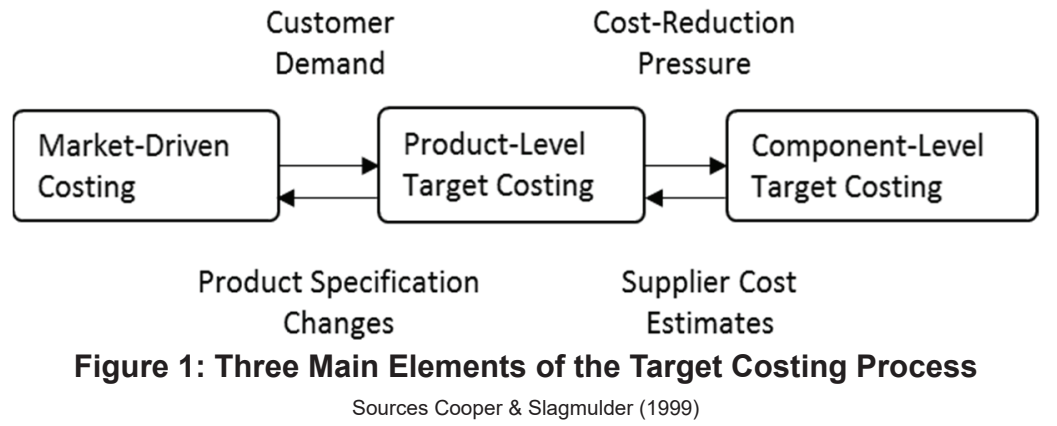


Market-Driven Costing: this the first section in the target costing process, where a product's allowable cost is identified from studying the market conditions and the determination of a company's profit margin.

Product-Level Target Costing: this level concentrates on designing products that satisfy the company's customers at a derived allowable cost.

Components-Level Target Costing: this section involves monitoring the relationship between the target cost and the estimated product cost at any point during the design process and ensuring that the total target costs at the component-level does not exceed the target cost of the product.

From the TC processes of the US firms shown in Figure 2, a very strict association between supply management and the design role in the TC practice was found to have existed at steps (1), (4), and (5), a trait that had been markedly different from those of the Japanese system, where the latter had focused more on the management accounting system (Cooper \& Slagmulder, 1999). According to Ellram (2006), the TC process can be further divided into a 6-step process as described in Figure 2. 


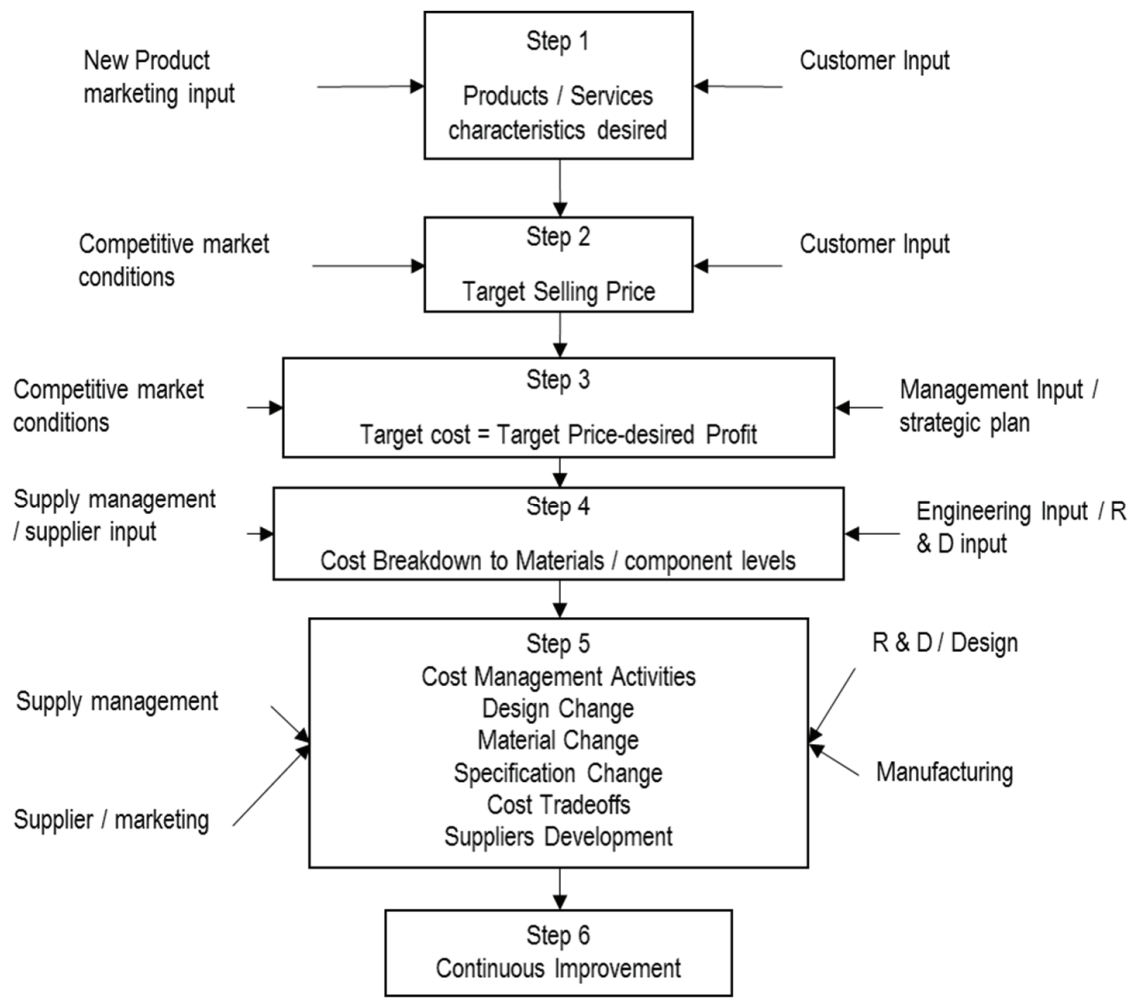

Figure 2: Target Costing Process

Sources: Ellram (2006)

\section{Dynamic Capability (DC)}

Although the association between TC and the DC of a product development had been highlighted in the literature (Verona \& Ravasi, 2003; Marsh \& Stock, 2006; Prieto et al., 2009; Alpenberg \& Scarbrough, 2013 and Abdul-Rahman et al., 2014), this study had however, opted to use the same instruments employed by Alpenberg and Scarbrough (2013) and Abdul-Rahman et al. (2014) in their respective observations of the TC implementation in Swedish publicly traded companies as well as the target costing implementation and organizational capabilities of those practiced in Malaysia and Thailand. According to Danneels (2002), the dynamics of product novelty are closely associated with a firm's competence level, a sentiment that is also shared by Verona and Ravasi (2003), Marsh and Stock (2006) and (Prieto et al., 2009), where they had argued that product 
development as having an essential role for creating dynamic capabilities through concepts integration and knowledge preservation and the continuous product improvements as being spurred by the combination of autonomy, performance management, support and trust given by the top management.

Apart from Teece et al. (1997) who had described dynamic capabilities as the underlining efficiency and the firm's specific capabilities for attaining a competitive advantage (Teece et al., 1997; Knight \& Collier, 2009), DC was also discovered to have been used for resolving issues related to concept development as well as product and process engineering in addition to being a pacer production and market starter (Marsh \& Stock, 2006; Prieto et al., 2009).

In another research conducted by Yeshmin and Hossan (2011), where they had tried to gauge the resistance on the usage of management accounting methods in the decision making of the manufacturing organizations in Bangladesh, the researchers had not only found the importance of accounting management method adjustments as providing a more effective management decision, these alterations had also allowed the organization to tap on its innovative capacity and flexibility that consequently leads to an improved company performance.

The research that was conducted by Abdul-Rahman et al. (2014) on the implementation of TC and DC of two Asian countries, namely Thailand and Malaysia, had also found the support rendered by the top management, cross-functional transfer of employees and job rotations to be the critical key factors of a fruitful TC implementation that were reflected by better quality products with improved designs, technologies, development processes as well as those of cost and waste reduction. These results were in line with those obtained from a prior study conducted by Alpenberg and Scarbrough (2013), where the consequence of DC from the TC implementation system in Sweden was discovered to have been significant for predicting PR. Apart from this, the researchers had also suggested biases that might have occurred in the development of the dynamic capability research, particularly the lean production systems that had not adhered to the organization practices seen in Japan. 


\section{Success Factors (SF)}

SF is known to be vital for a successful TC implementation, where according to Ansari et al. (1997), leadership is considered to be one of the key elements from the several factors (e.g. behavioural, culture, technical/ structural and political) listed. While behavioural factors had involved communication, motivation, morale and performance measurement, cultural factors on the other hand had entailed placing the focus on customers, cross functional cooperation, openness and trust among the employees. Technical/ structural factors were also found to affect the success of a TC implementation through proper data collection methods and investments with well-equipped cross-functional teams. As for political factors, these had included buy-ins from managers, suppliers and employees as shown by the study conducted by Huang et al. (2012). By using the Market Orientation Theory to relate the implementation of a TC system and the business model innovation company performance of the electronics and information industry manufacturers in China, they had successfully demonstrated the business model innovation as being positively associated to the company's performance. In another study, Chan et al. (2010) had also positively identified four critical SFs, namely the (1) reasonable share of cost saving and fair risk allocation; (2) patterning spirit from all contracting parties; (3) valid selection of the project team; and (4) vivid definition scope of work in a client's project and the early involvement of contractor in design development as influencing the TC contracts and the guaranteed maximum prices of the construction industry in Hong Kong. While examining the benefits of optimal outcome sharing arrangement between the risk-neutral and risk-averse contractors within the consortium and a risk-neutral owner, Hosseinian and Carmichael (2014) had also suggested for a reduced outcome sharing proportion to a consortium of risk-averse contractors and an increased fixed component of the consortium fee for more risk-averse contractors.

Although Tani et al. (1994) had identified the product design and planning departments as being highly involved in the TC process, it is also important to note that the results obtained by Alpenberg and Scarbrough (2013) from a prior study had found the SF from the implemented TC system in Sweden as having an insignificant effect on the PR. Based on a study that was conducted on the implementation of the TC management (TCM) at a Japanese shipbuilding company, Yasukata et al. (2013) had 
also indicated the diffusion of TCM to be a consequence of a thoughtful managerial activity and its susceptibility to failure as being resulted from the lack of appropriate supervision over the TCM implementation project hence, suggesting the TCM as not being naturally diffused throughout an organisation, but rather control is required for overseeing its successful implementation.

\section{Dysfunctional Behaviour (DB)}

While examining target costing in the presence of product and production interdependencies, Kee and Matherly (2014) had found a product's cost reduction effort as not being independently determined by other production-related choices, such as those of product mix, capacity and price. For this reason, the suboptimal target costing decisions were not only found to have an impact on the products and product mix that the firm chooses to offer, but are also seen as affecting the ability of organizations for effectively achieving their strategic goals. As such, the new limitations to target costing that had been identified from their study would then be deemed as useful for managers to have a better understanding on the technique used and consequently, leading to better and improved target costing decisions. Under this circumstance, TC implementation is found to have played a role in triggering the DB actions apart from aiding in cost reduction and improved product quality.

Several DB such as in the forms of employees' burnout and departmental conflicts were also found to have occurred as a result of the TC implementation system (Ansari et al., 1997; Kato et al., 1995; Zengin \& Ada, 2010), where its main deficiency could have resulted from the failure of incorporating capital cost into the production-related decisions (Kee, 2010). While it had seemed that a higher DB level would lead to a lower $\mathrm{PR}$, the result of a prior research conducted by Alpenberg and Scarbrough (2013) had apparently stated otherwise. For this reason, a few hypotheses that had been based on the results of the prior studies were then proposed for studying its impact on the manufacturing companies in Indonesia.

Lastly, several studies had also identified a number of dysfunctional aspects such as an overemphasis on customer orientation that eventually leads to market confusion and time extension for new product introduction; 
employees' and suppliers' burnout and those of departmental conflicts as arising from an implemented TC system (Ansari et al., 1997; Kato et al., 1995; Chandrarin, 2013).

\section{RESEARCH METHODOLOGY}

This section not only explains the research methods and the supporting references that were used in this study, but also examines the measured influence of the TC implementation on the dynamic capabilities (DC), dysfunctional behaviours (DB), success factors (SF) and the target costing performance result (PR) of Indonesian manufacturing companies from the use of a causality designed and descriptive-quantitative method. The number of Indonesian companies that had successfully used the TC system in determining the cost and sales price of the product were also established from this research.

\section{Data and Sample}

The primary data of the listed and unlisted manufacturing companies in the Jakarta Stock Exchange (JSE) were gathered through the use of questionnaires. From a targeted population of 329 manufacturing companies that were chosen through the random sampling method, the total data collected had was obtained from 65 respondents, most of them consisting of financial, accounting, production and information technology managers.

The data that were obtained from the targeted population were then analysed using multiple regression analysis with the following statistical equation (Chandrarin, 2017):

$$
\mathrm{PR}=\alpha 0+\alpha 1 \mathrm{DC}+\alpha 2 \mathrm{SF}+\alpha 3 \mathrm{DB}+\varepsilon
$$

Note:

$\mathrm{PR}=$ Target Costing Performance Results

$\mathrm{DC}=$ Dynamic Capabilities

$\mathrm{SF}=$ Success Factors

$\mathrm{DB}=$ Dysfunctional Behaviours 


\section{Hypotheses Formulation}

Based on the suggestion provided by the prior studies, this research had therefore aimed to observe the influence of TC implementation on the $\mathrm{DC}, \mathrm{SF}$ and DB of the Indonesian manufacturing firms by proposing the following hypotheses (see Figure 3 of the hypothesis formulation scheme):

$\mathbf{H}_{\mathbf{1}}$ : Dynamic capabilities have a statistically significant effect on target costing performance results.

$\mathbf{H}_{2}$ : Success factors have a statistically significant effect on target costing performance results.

$\mathbf{H}_{3}$ : Dysfunction behaviours have a statistically significant effect on target costing performance results.

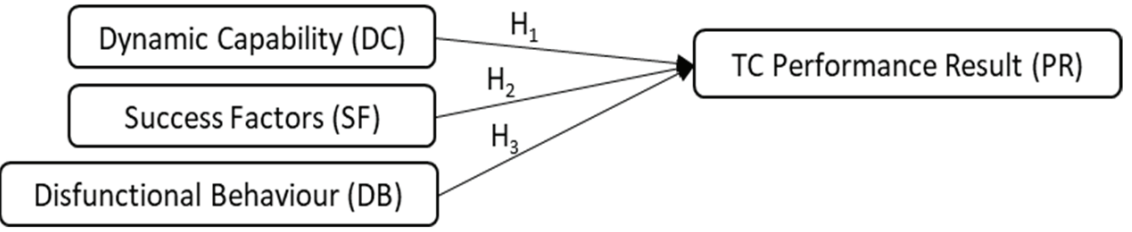

Figure 3: Hypothesis Formulation

\section{Questionnaire Result}

From the results that were gathered from 65 of the respondents, 17 and 15 of them were found to be from the corresponding automotive and electronics industries, while 10 had been from household items and consumer products and the rest consisting of various industries. Although the aim of this study is to have a better understanding on the respondents' concept of the TC system from those of the automotive companies, the low response rate from the participants however, were found to have been due to the: (1) unstable political situation (employee demonstration); (2) busy schedule; (3) a high resistance and sensitivity level of the respondents and (4) the low conceptual understanding among the participants.

The validity test of the questionnaire analysis was conducted with a product-moment correlation coefficient of $\alpha=5 \%$, whereby the reliability test on the questionnaire analysis had shown all the variables $(\mathrm{DC}=0.9387$; $\mathrm{SF}=0.9331 ; \mathrm{DB}=0.5566$ and $\mathrm{PR}=0.8793)$ exceeding the Cronbach's 
Alpha of 0.241 hence, implying that the variables as sharing a covariance and had probably measured the same underlying concept.

\section{Research Instrument Test}

All of the observed variables, namely the PR, DC, SF and DB that were obtained from the questionnaires of the respondents were then used for conducting this research in Indonesia. These same questionnaires were also employed by the researchers of other countries, such as Alpenberg and Scarbrough (2013) in Sweden and Abdul-Rahman et al. (2014) in Malaysia and were subsequently generalized to be used in the Asia Pacific region.

From the 49 items contained in the questionnaire, 15 of the items were on measuring TC implementation in Indonesia, while 12, 18 and 4 items had touched on the respective DC, SF and DB factors. The questionnaire used a 5-point Likert scale as a way of gauging the respondents' agreement with a variety of the statements provided.

\section{RESULTS AND DISCUSSION}

Apart from reporting the projected results from the implemented TC system in Indonesia, this section will also explain the results that had been derived from the descriptive statistical analyses conducted on each of the affected variable.

\section{Explanation of the Descriptive Statistical Research}

The three independent variables of DC, SF, DB and the single dependent variable PR were measured using a 5-point Likert scale. Based on the results obtained from the frequency distribution, the average mean for DC was 3.04 (the highest being 3.41), while those of the SF, DB and PR were discovered to have the respective average mean values of 3.56 (the highest being 4.41), 2.95 (the highest being 3.50) and 3.11 (the highest being 3.56). As DC was found to have demonstrated the highest average mean value, it therefore implies that the product development team had produced many new novel and useful ideas that were supported by the top management as reflected by the SF mean value. While an overemphasis on customer orientation (e.g. diversified products) was found to have the 
biggest impact on the $\mathrm{DB}$, the realization of product concept was considered as being the dominant perception for measuring PR.

Table 2: Mean Data of the DC Item List from the Questionnaire (using a Likert Scale to denote 1 as "not correct" and 5 as "very correct")

\begin{tabular}{clc}
\hline No. & \multicolumn{1}{c}{ Item List Dynamic Capabilities (DC) } & Mean of DC \\
\hline 1 & New findings and useful ideas & 3.41 \\
\hline 2 & Resolve the issue of consumer dissatisfaction & 3.12 \\
\hline 3 & Resolve the issue through product improvements & 3.06 \\
\hline 4 & Merging new knowledge, methods and findings & 3.03 \\
\hline 5 & Integrate new and old ways without hampering efficiency & 2.9 \\
\hline 6 & Apply knowledge gained from other departments & 2.83 \\
\hline 7 & Using technical and marketing competencies & 2.95 \\
\hline 8 & Be able to identify, connect and incorporate elements of & 3.15 \\
\hline 9 & knowledge & 2.95 \\
\hline \multirow{2}{*}{10} & $\begin{array}{l}\text { Controducing changes beyond existing product / service feature } \\
\text { within and outside the company }\end{array}$ & 3.13 \\
\hline 11 & Teach team knowledge to the entire organization & 2.7 \\
\hline 12 & Able to receive new knowledge & 3.23 \\
\hline & Average all items of DC & 3.04 \\
\hline
\end{tabular}

Source: Primary Data Processed

As shown in Table 2, the highest average answer concerning the discovery of new ideas and ideas for the DC had been on "1", which was then followed by the ability of gaining new knowledge and the identification and coordination of new sciences within the company. This therefore suggests that the most influential factor of TC implementation of a manufacturing company had been on finding new ideas for product development, while the most difficult task had been on coordinating the new ideas across the whole company. 
Table 3: Mean Data of the SF Item List from the Questionnaire (using a Likert Scale to denote 1 as "not important" and 5 as "very important")

\begin{tabular}{clc}
\hline No. & \multicolumn{1}{c}{ Item List Success Factors (SF) } & $\begin{array}{c}\text { Mean of } \\
\text { SF }\end{array}$ \\
\hline 1 & Quality management support & 4.41 \\
\hline 2 & Equipment and information systems & 4.1 \\
\hline 3 & Cooperation with suppliers & 3.67 \\
\hline 4 & Cooperation with other departments & 3.95 \\
\hline 5 & Empowerment of project managers & 3.3 \\
\hline 6 & Ability to estimate cost of product & 4.23 \\
\hline 7 & Competition in engineering & 4.01 \\
\hline 8 & Forming cross-functional teams & 2.78 \\
\hline 9 & Cross-functional employee rotation & 2.5 \\
\hline 10 & Job rotation & 2.35 \\
\hline 11 & Sharing information & 3.15 \\
\hline 12 & Labour autonomy & 2.63 \\
\hline 13 & Delegation of authority and responsibility & 3.41 \\
\hline 14 & Linkage to profit planning & 4.07 \\
\hline 15 & New technology / materials from research and development & 3.95 \\
\hline 16 & Technology in production \& quality & 4.27 \\
\hline 17 & Functional knowledge of team members & 3.06 \\
\hline 18 & Knowledge of cost of goods manufactured & 4.16 \\
\hline & Average all items of SF & 3.56 \\
\hline
\end{tabular}

Source: Primary Data Processed

In Table 3, quite a number of the respondents had cited quality management support (QMS), technology or quality and the ability of estimating a product's production cost as being important SFs, while job rotations as having the least influence. This therefore indicates that the effect of the TC implementation on the SF factor is very much influenced by the QMS implementation of a company as reflected by its first-rate product quality control system and product cost estimation. 
Table 4: Mean Data of the DB Item List from Questionnaire (using a Likert Scale to denote 1 as "never" and 5 as "always")

\begin{tabular}{clc}
\hline No. & \multicolumn{1}{c}{ Item List Dysfunctional Behaviours (DB) } & Mean of DB \\
\hline 1 & Supplier reduction & 2.7 \\
\hline 2 & Increased conflict & 2.9 \\
\hline 3 & Reduction of target costing design & 2.66 \\
\hline 4 & Too many orientations to customers to diversify & 3.5 \\
\hline & Average all items of DB & 2.94 \\
\hline
\end{tabular}

Source: Primary Data Processed

As seen in Table 4, the DB factor can be considered as having the lowest perception average value, where the highest perception score was found to have been the customer diversified orientation, while the subsequent items had been those of internal conflicts and the reduction of the target costing design. Hence, it can be concluded that a majority of the manufacturing companies in Indonesia still lacked the ability of producing merchandises that are in accordance with the needs of the customer. For this reason, the possible high cost implications on research and development can thus be mitigated by extending the product life cycle through an implemented quality control maintenance system that was mentioned earlier.

\section{Results of Normality, Multicollinearity, Autocorrelation and Heteroscedasticity Tests}

The respective VIF scores of DC (3.131), SF (3.165) and DB (1.046) with less than 5 had indicated the absence of multicollinearity issue among the variables or in other words, the non-correlation of independent variables in a regression model.

There was also no autocorrelation bias detected from the Durbin Watson test as shown by its score of 1.120 (between the range of -2 and 2) thus, denoting the absence of a similarity between a given time series and a lagged version of itself over the successive time intervals.

Since a good regression model is assumed to consist of normally distributed residuals, the normality test that was conducted via graph analysis in Figure 4 had therefore shown that the data as having a normal distribution with a bell-shaped density curve. 
The absence of heteroscedasticity bias that was reflected in the scattered plot diagram between the prediction value of dependent variable (ZPRED) and those of the residuals (SRESID) in Figure 5 had also proven the modelling errors as being uniform and uncorrelated.

Histogram

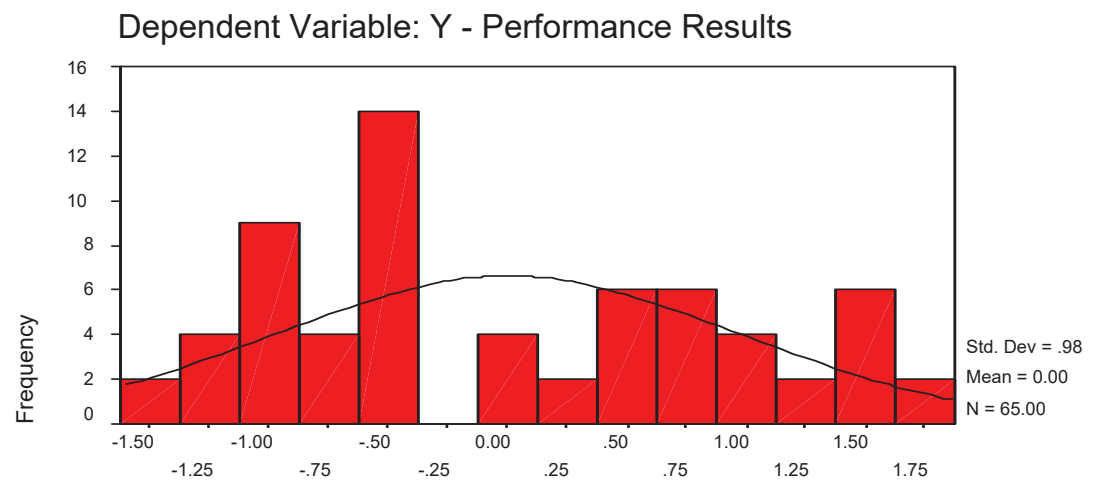

Regression Standardized Residual

Figure 4: Data Distribution

Scatterplot

Dependent Variable: Y - Performance Results

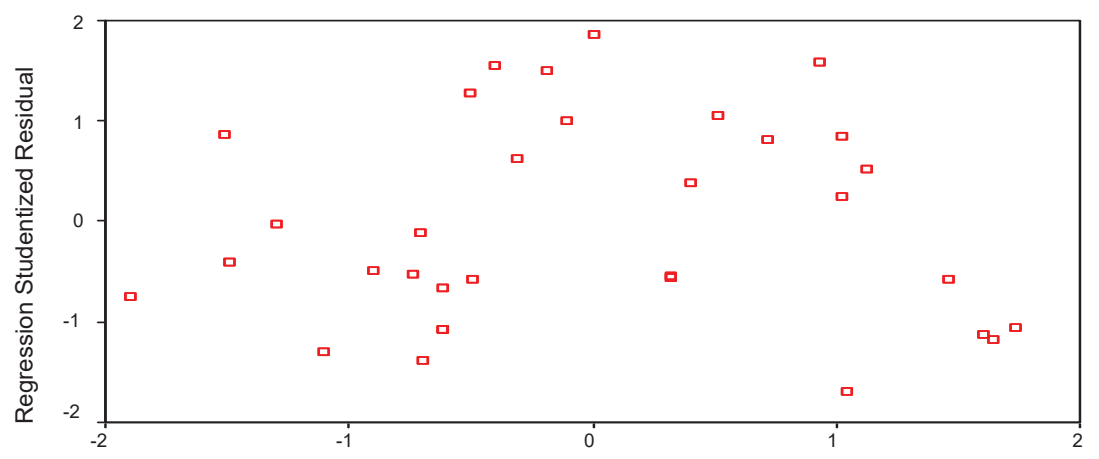

Regression Standardized Predicted Value

Figure 5: Scatter Plot Diagram from Data Regression 


\section{Results of Hypotheses Testing}

The three hypotheses that were being formulated for this study had aimed to (i) examine the outcome from DC, (ii) identify the SF from the TC implementation and to (iii) identify the effects of DB on PR. As for the results obtained from the ordinary least square regression, the F-test was found to have a value of $30.457(\mathrm{p}=000)$, while the overall model was discovered to be statistically significant at the $\alpha=5 \%$ and the adjusted R2 value of 0.580 had denoted $58 \%$ of the PR as being influenced by the DC, $\mathrm{SF}$, and DB factors. The results of the ordinary least square regression analysis are thus shown in Table 5.

Table 5: Results of the Multiple Regression Analysis $P R=\alpha 0+\alpha 1 D C+\alpha 2 S F+\alpha 3 D B+\varepsilon$

\begin{tabular}{lcccc} 
Variables & $\begin{array}{c}\text { Coefficients } \\
\text { Standardized }\end{array}$ & $\begin{array}{c}\text { Standard } \\
\text { Error }\end{array}$ & t value & p value \\
\hline Dynamic Capabilities & 0.665 & 0.133 & 4.64 & ${ }^{*} 0.000$ \\
Success Factors & -0.020 & 0.097 & -0.14 & 0.889 \\
Dysfunctional Behaviours & -0.323 & 0.303 & -3.89 & ${ }^{*} 0.000$ \\
\hline
\end{tabular}

* Statistically significant at level $\alpha=5 \%$.

While the DC was found to have a positive statistically significant effect on the PR at a t-value of 4.64, a p-value of 0.000 as well as a 0.665 coefficient with a standard error of 0.133 , the effect of the success result on the PR was however proven otherwise at the respective $t$ - and $p$-values of -0.14 and 0.889 . By demonstrating a negative $t$-value of -3.89 , p-value of 0.000 , the coefficient standardized value of -0.323 and a 0.303 standard error value, the $\mathrm{DB}$ was discovered to have a negative statistically significant effect on the PR thus, denoting the TC implementation as resulting in an inverse relationship between the $\mathrm{DB}$ and $\mathrm{PR}$.

The relationship between the three independent variables and the dependent variable that was subsequently tested with the use multiple correlation analysis $(\mathrm{R})$ had also validated the close relationship between the Dynamic Capabilities (X1), Success Factors (X2) and Dysfunctional Behaviour (X3) with the Performance Results (Y) as shown by its correlation coefficient (R) of 0.774 . 
Although the adjusted R2 of 0.58 had shown the variables as demonstrating a $58 \%$ contributory effect to the dependent variable and the remaining $42 \%$ from the elements / variables that were excluded from the model, the independent variables were found to have demonstrated a reasonable prediction on the future outcome of the dependent variable.

Based on the above results, the DC and DB were not only found to have strong influences on the TC system implementation, but a lower DB was also discovered as leading to a higher PR level. On the contrary, SF was not considered as one of the main factors for determining the successful implementation of the TC system since the indicators of its influence were found to be caused by the 1) delegation of power/responsibility; 2) autonomy of employees; 3 ) cross-functional team (organizational structure); 4) cooperation with suppliers and 5) information sharing.

For this reason, while it had seemed impossible that the SF had no influence on the implementation of a TC system, further research is therefore suggested for exploring the possible influences of the SF from an implemented TC system.

\section{CONCLUSION}

The observation on the implementation of a TC system at various manufacturing companies such as those from the automotive, electronic, household items and consumer products industries in various parts of Indonesia was conducted through the use of descriptive statistical analysis. Based on the results of the analysis, the most dominant perception was found to be the dynamic capabilities (DC) that were influenced by the novel and useful ideas produced by the product development team, which was then followed by the top management support for the SF, the DB as being related to the overemphasis on customer orientation and the realization of the product concept for influencing the PR. Hence, it can be surmised that consideration should be given to the DC, SF, DB and PR factors prior to the implementation of any TC systems.

The hypotheses that were developed in this study had not only discovered the DC and DB as having a statistically significant effect on 
the PR, but also a lower DB from the implemented TC system. Although the result is in line with the study conducted by Alpenberg and Scarbrough (2013), where they had stated a higher level DC as leading to a strong TC performance, the success results and DB however, were not found to have a significant impact on the PR.

It is also important to note that most of responses provided on the implemented TC system had shared a similar connotation, although different terms and forms were used to describe the implemented TC systems.

Since this study had only focused in the manufacturing firms in Indonesia, further research is therefore recommended for investigating the implemented TC systems of other countries as a way of increasing its validity across the Asia Pacific and international regions. As a result, the comparative analyses that can be conducted between the US, Japan, Sweden, Thailand and Malaysia will certainly provide a much more detailed finding on the impacts of an implemented TC system. Apart from this, further research can also be performed to address the modelling concept of the implemented TC system and the prediction capability evaluation of other models. The usage of various theories for example, the triangulation theory, will not only provide a better understanding of the data analysis, but also a generalization of the results if the various theories are shown to produce the same and consistent conclusions.

\section{ACKNOWLEDGEMENT}

The authors would like to convey their gratitude to Prof. Susumu Ueno of Konan University Japan for sharing his ideas during the APMAA conference in China, Dr. Prihat Assih, Dr. Diana Zuhroh, Rus Ambarwati and all colleagues from the Postgraduate School of University of Merdeka Malang for providing their insight and expertise in this research. Last but not least, the authors would like to extend their appreciation to the Ministry of Research, Technology and Higher Education for their generous financial support in funding this research. 


\section{DISCLOSURE STATEMENT}

This research had been financially supported by the Ministry of Research, Technology and Higher Education. The authors declare that there is no conflict of interest regarding the publication of this article.

\section{REFERENCES}

Abdul-Rahman, I., Omar, N. S., Hui, W., \& Syaraf-Addin, H. (2014). Target Costing Implementation and Dynamic Capabilities: An Empirical Evidence of Selected Asian Countries. Unpublished Proceeding of 2014 APMAA Annual Conference.

Afonso, P., Nunes, M., Paisana, A., \& Braga, A. (2008). The influence of time-to-market and TC in the new product development success. International Journal of Production Economics, 115(2), 559-568.

Alpenberg, J., \& Scarbrough, D. P. (2013). Dynamic capabilities and target costing in Swedish publicly traded companies. Asia-Pacific Management Accounting Journal, 8(2), 89-121.

Ansari, S. L., \& Bell, J. E. (1997). Target costing - The next frontier in strategic cost management. Chicago: Irwin.

Chan, A. P. C., Lam, P. T. I., Chan, D. W. M., Cheung, E., \& Ke, Y. (2010). Critical success factors for PPPs in infrastructure developments: Chinese perspective. Journal of Construction Engineering and Management, 136(5), 484-494.

Chandrarin, G. (2013). The direction of future management accounting research in the Asia Pacific region. Paper presented at the International Conference On Law, Business and Governance (ICon-LBG). Retrieved from https://media.neliti.com/media/publicatio ns/172302-EN-thedirection-of-future-management-accou.pdf

Chandrarin, G. (2017). Accounting Research Method - Quantitative Approach. Jakarta: Salemba Empat Publisher. 
Cooper, R., \& Slagmulder, R. (1999). Develop profitable new products with target costing. Sloan Management Review, 40(4), 23-33.

Danneels, E. (2002). The dynamic of product innovation and firm competences. Strategic Management Journal, 23(12), 1095-1121.

Dekker, H., \& Smidt, P. (2003). A survey on the adoption of use of target costing in Dutch firms. International Journal of Production Economics, 84, 293-305.

Ellram, L. M. (2006). The implementation of target costing in the United States: Theory versus practice. Journal of Supply Chain Management, 42(1), 13-26.

Feil, P., Yook, K. H., \& Kim, I. W. (2004). Japanese target costing: A historical perspective. International Journal of Strategic Cost Management, 10-19.

Filomena, T. P., Jose, F., Neto, K., \& Duffey, M. R. (2009). Target costing operationalization during product development: Model and application. International Journal of Production Economics, 118, 398-409.

González, F. J. M., \& Palacios, T. M. B. (2002). The effect of new product development techniques on new product success in Spanish firms. Industrial Marketing Management, 31(3), 261-271.

Griffin, A. (2002). Product development cycle time for business-to-business products. Industrial Marketing Management, 31(4), 291-304.

Gupta, A. K., Brockhoff, K., \& Weisenfeld, U. (1992). Making trade-offs in the new product development process: A German/US comparison. Journal of Product Innovation Management, 9(1), 11-18.

Hamood, H. H., Omar, N., \& Sulaiman, S. (2011). Target costing practices: A review of literature. Asia-Pacific Management Accounting Journal, $6(1), 25-46$. 
Herdhayinta, H., Chandrarin, G., Sumiyana, \& Fitrianto, A. (2017). The influence of board diversity on financial performance: An empirical study of Asia-Pacific companies using regression models. International Business Management, 11(1), 89-99.

Hosseinian, S. M., \& Carmichael, D. G. (2014). Optimization in the development of target contracts. In: Xu H., Wang X. (Ed.), Optimization and control methods in industrial engineering and construction. intelligent systems, control and automation: science and engineering (pp. 259-296). Dordrecht: Springer.

Huang, H.-C., Lai, M.-C., Kao, M.-C., \& Chen, Y.-C. (2012). Target costing, business model innovation, and firm performance: An empirical analysis of Chinese firms. Canadian Journal of Administrative Sciences, 29(4), $322-335$.

Huh, S., Yook, K. H., \& Kim, I. W. (2008). Relationship between organizational capabilities and performance of target costing: An empirical study of Japanese companies, Journal of International Business Research, 7(1), 91-107.

Kato, Y., Boer, G., \& Chow, C. W. (1995). Target Costing: An integrative management process. Journal of Cost Management, 9(1), 39-51.

Kee, R. (2010). The sufficiency of target costing for evaluating productionrelated decisions. International Journal of Production Economics 126(2), 204-211.

Kee, R., \& Matherly, M. (2014). Target costing in the presence of product and production interdependencies. Advances in Management Accounting, 22, 135-158.

Knight, K., \& Collier, P. M. (2009). Target costing in the automotive industry: A case study of dynamic capabilities. Retrieved from https:// ssrn.com/abstract $=1404366$.

Kocsoy, M., Gurdal, K., \& Karabayir, M. E. (2008). Target costing in Turkish manufacturing enterprises. European Journal of Social Sciences, 7(2), 92-105. 
Marsh, S. J., \& Stock, G. N. (2006). Creating dynamic capabilities: The role of intertemporal integration, knowledge retention and interpretation. Journal of Product Innovation Management, 23(5), 422-436.

Meghabber, F. Z. (2015). Reduce costs in the modern manufacturing environment case study with implementation of target costing and e-constraint method. European Scientific Journal, 16(11), 134-144.

Mohamad, E., \& Ito, T. (2013) Integration of e-learning and simulation to user training programme of SMED. International Journal of Internet Manufacturing and Services, 3(2), 121-136.

Prieto, I. M., Revilla, E., \& Rodriguez-Prado, B. (2009). Building dynamic capabilities in product development: How do contextual antecedents matter? Scandinavian Journal of Management, 25, 313-326.

Sherman, J. D., Souder, W. E., \& Jenssen, S. A. (2000). Differential effects of the primary forms of cross functional integration on product development cycle time. Journal of Product Innovation Management, 17(4), 257-267.

Suhardianto, N., Subroto, B., \& Chandrarin, G. (2017). Mapping marketbased accounting research in Indonesia: Graphics and guidelines for future research. Asian Journal of Accounting Research, 2(1), 18-44.

Tani, T. (1995). Interactive control in target cost management. Management Accounting Research, 6, 399-414.

Tani, T., Okano, H., Shimizu, N., Iwabuchi, Y., Fukuda, J., \& Cooray, S. (1994). Target cost management in Japanese companies: Current state of the art. Management Accounting Research, 5, 67-81.

Teece, D., Pisano, G., \& Shuen, A. (1997). Dynamic capabilities and strategic management. Strategic Management Journal, 18(7), 509-533.

Verona, G., \& Ravasi, D. (2003). Unbundling dynamic capabilities: An exploratory study of continuous product innovation. Industrial and Corporate Change, 12(3), 577-606. 
Yasukata, K., Yoshida, E., Yamada, I., \& Oura K., (2013). A longitudinal case study of target cost management implementation at a shipbuilding company. Journal of Accounting and Organizational Change, 9(4), $448-470$.

Yazdifar, H., \& Askarany, D. (2011). A comparative study of the adoption and implementation of TC in the UK, Australia and New Zealand. International Journal of Production Economics, 135, 382-392.

Yeshmin, F., \& Hossan, A., (2011). Signicance of management accounting techniques in decision-making: An empirical study on manufacturing organizations in Bangladesh. World Journal of Social Sciences, 1(1), $148-164$.

Yuniawan, D., Ito, T., \& Mohamad, E. (2013). Calculation of overall equipment effectiveness weight by Taguchi method with simulation. Journal of Concurrent Engineering Research and Application, 21(4), 296-306.

Yuniawan, D., Ito, T., \& Mohamad, E. (2014). Overall equipment effectiveness estimation for priority improvement in the production line. International Journal of Internet Manufacturing and Services, 3(4), 279-299.

Zengin, Y., \& Ada, E. (2010). Cost management through product design: Target costing approach. International Journal of Production Research, 48(19), 5593-5611. 